\title{
PENGGUNAAN KERTAS ORIGAMI UNTUK MENINGKATKAN KETERAMPILAN MOTORIK HALUS MELALUI KEGIATAN MENGGUNTING BERPOLA KELOMPOK B TK EL-IZDIHAR-RAJEG
}

\author{
Nia Kurniasih ${ }^{1}$, Ahmad Yanuar Syauki ${ }^{2}$, dan Ana Lisnia ${ }^{3}$ \\ ${ }^{1}$ Sekolah Tinggi Keguruan dan Ilmu Pendidikan Banten \\ ${ }^{2}$ Sekolah Tinggi Keguruan dan Ilmu Pendidikan Banten \\ ${ }^{3}$ Sekolah TK El-Izdihar Rajeg \\ Penulis Korespondensi : niakurniasih743@gmail.com ${ }^{1}$, aysyauki@yahoo.com², \\ lisniaana@gmail.com ${ }^{3}$ \\ Artikel: Kemampuan Mengenal Warna \\ Penerima: Januari, 2021 \\ Diterima: februari, 2021 \\ Dipublikasikan: Maret, 2021
}

\begin{abstract}
This study aims to improve fine motor skills using origami paper media through group B patterned cutting activities at El-Izdihar Kindergarten, Rajeg District, Tangerang Regency. This research is a collaborative Classroom Action Research (CAR) which was carried out in 2 cycles. The subjects of this study were group B children in El-Izdihar Rajeg Kindergarten, totaling 10 children. This research was conducted in the first semester of the 2020/2021 Academic Year. The data collection technique used in this research is observation. The data collection instrument used an observation sheet. The improvement of fine motor skills is said to be successful if the percentage of children's fine motor skills reaches $80 \%$ with good or very increased criteria. After taking action in cycle I and cycle II, the achievement of good criteria with a percentage value of fine motor skills is $90 \%$.
\end{abstract}

Key words : Origami paper, Fine motor skills, Pattern cutting

\begin{abstract}
ABSTRAK
Penelitian ini bertujuan untuk meningkatkan keterampilan motorik halus dengan menggunakan media kertas origami melalui kegiatan menggunting berpola kelompok B di TK El-Izdihar Kecamatan Rajeg Kabupaten Tangerang. Penelitian ini merupakan Penelitian Tindakan Kelas (PTK) kolaboratif yang dilaksanakan dalam 2 siklus. Subjek penelitian ini adalah anak-anak kelompok B di TK El-Izdihar Rajeg yang berjumlah 10 anak. Penelitian ini dilaksanakan pada semester I Tahun Ajaran 2020/2021. Teknik pengumpulan data yang digunakan dalam penelitian ini adalah observasi. Instrumen pengumpulan data menggunakan lembar observasi. Peningkataan kemampuan motorik halus yang dikatakan berhasil apabila persentase kemampuan motorik halus anak mencapai $80 \%$ dengan kriteria baik atau sangat meningkat. Setelah dilakukan tindakan pada siklus I dan siklus II pencapaian kriteria baik dengan nilai presentase keterampilan motorik halus sebesar $90 \%$.
\end{abstract}

Kata kunci : Kertas origami, Motorik halus, Menggunting berpola 


\section{PENDAHULUAN}

Masa usia dini merupakan periode emas (golden age) bagi perkembangan anak untuk memperoleh proses pendidikan. Periode ini anak seperti sponges dimana anak dapat menyerap dengan mudah segala sesuatu yang dilihat dan didenarnya. Periode ini adalah tahun-tahun berharga bagi seorang anak untuk mendapatkan stimulasi dalam semua aspek perkembangannya, karena itu sebaiknya orang tua memberikan pendidikan sedini mungkin kepada anak.

Menurut Sujiono, (2013) motorik adalah semua gerakan yang mungkin dapat dilakukan oleh seluruh tubuh, sedangkan perkembangan motorik dapat disebut sebagai perkembangan dari unsur kematangan dan pengendalian gerak tubuh. Perkembangan motorik anak terbagi menjadi dua bagian yaitu gerak motorik kasar dan gerak motorik halus. Gerak motorik kasar adalah kemampuan yang membutuhkan koordinasi sebagian besar bagian tubuh, sedangkan motorik halus adalah gerakan yang hanya melibatkan bagian-bagian tubuh tertentu saja dan dilakukan oleh otot-otot kecil, seperti menggunakan jari-jemari tangan dan pergelangan tangan yang tepat. Perkembangan motorik halus pada anak usia dini merupakan perkembangan yang sangat penting bagi anak. Gerakan motorik halus lebih membutuhkan gerakan koordinasi mata dan tangan anak. Dengan koordinasi antara mata dan tangan yang sudah semakin baik maka anak sudah dapat mengurus dirinya sendiri dengan lebih mandiri tentunya dengan pengawasan orang tua. Setiap anak mampu mencapai tahap perkembangan motorik halus yang optimal apabila mendapatkan stimulasi yang tepat. Anak membutuhkan rangsangan untuk mengembangkan kemampuan mental dan motorik halusnya.

Anak kelompok B di TK El-lzdihar Rajeg, Tahun Ajaran 2020/2021, kemampuan gerak atau motorik halus masih kurang, dilihat dari cara mereka memegang gunting dan membuat pola. Menurut hasil wawancara dengan guru kelas B TK El-lzdihar Rajeg, hal ini dibuktikan adanya anak dalam menggunting bentuk belum bisa rapih. Anak dalam menggunting berpola kertas origami banyak hasil yang kurang baik, anak kurang mengkoordinasikan gerakan tangan dan mata. Saat anak diberi kegiatan menggunting anak sering meminta bantuan gurunya untuk menyelesaikan guntingannya.

Penelitian ini adalah anak berusia 5- 6 tahun pada kelompok B lembaga pendidikan anak usia dini . Siswa yang diteliti sebanyak 10 orang, 4 siswa lakilaki, 6 orang siswi perempuan. Lokasi penelitian merupakan tempat dilakukannya penelitian tersebut. Pada penelitian ini adalah lembaga kelas kelompok B TK El-Izdihar. Begitu pentingnya masa pertumbuhan dan perkembangan ini sehingga apabila terjadi kegagalan pada masa ini dapat mengakibatkan kegagalan di masa - masa berikutnya. Oleh karena itu, pendidikan untuk anak usia dini perlu diperhatikan untuk mengoptimalkan seluruh potensi yang dimiliki anak. Anak melakukan gerakan seperti memegang gunting dan memotong kertas merupakan bagian dari kegiatan motorik halus. Selain itu selama anak beberapa kali melakukan gerakkan menggunting dan membuat pola pada kertas tanpa disadari anak telah terangsang gerakan motorik halusnya.

Dari pengertian diatas dapat ditarik kesimpulan bahwa kegiatan menggunting berpola dapat meningkatkan keterampilan motorik halus pada anak usia dini 
| Nia Kurniasih, Ahmad Yanuar Syauki, dan Ana Lisnia. Penggunaan Kertas Origami Untuk Meningkatkan Keterampilan Motorik Halus Melalui Kegiatan Menggunting Berpola Kelompok B Tk El-Izdihar-Rajeg

Bersarkan latar belakang masalah yang telah dipaparkan diatas, maka rumusan masalah yang muncul adalah: Bagaimana meningkatkan perkembangan keterampilan motorik halus dengan menggunakan media kertas origami melalui kegiatan menggunting berpola.

\section{LANDASAN TEORI \\ Keterampilan Motorik Halus}

Keterampilan motorik halus merupakan kegiatan yang menggunakan otot halus pada tangan. Gerakan ini memerlukan kecepatan, ketepatan dan keterampilan menggerakan. Keterampilan motorik halus biasanya digunakan dalam kegiatan belajar di dalam ruangan.

Ahmad Susanto, (2015) Motorik halus adalah gerakan yang hanya melibatkan bagian-bagian tubuh tertentu saja dan dilakukan otot-otot kecil, karena itu tidak begitu memerlukan tenaga. Gerakan halus ini memerlukan koordinasi yang cermat. Contoh gerakan halus misalnya : Gerakan mengambil sesuatu benda dengan hanya menggunakan ibu jari atau menggunakan jari telunjuk, Gerakan memasukan benda kecil kedalam lubang, membuat prakarya (menempel, melipat, menggunting, meremas), menggerakan lengan, siku, sampai bahu dan lainnya.

Melalui latihan-latihan yang tepat, gerakan halus ini dapat ditingkatkan dalam hal kecepatan dan kecermatan. Sehingga secara bertahap seorang anak akan bertambah terampil dan mahir melakukan gerakan-gerakan yang diperlukan guna penyesuaian dirinya.

\section{Kegiatan Menggunting Berpola}

Luluk, (2011) mengungkapkan bahwa "keterampilan menggunting adalah kemampuan gerak halus antara tangan dan mata dalam kegiatan Pada penelitian pengembangan, penulis harus menuliskan (C) 2021, JoEE, Jurnal of Early Childhood. PGPAUD e-ISSN: 2775-7870 dengan jelas langkah-langkah pengembangan dan target pada setiap tahapan. Pada PTK, penulis harus dapat menunjukkan apa yang dilakukan memotong suatu benda. Menggunting merupakan kegiatan kreatif yang menarik bagi anak-anak. Menggunting termasuk tekhnik dasar untuk membuat aneka bentuk kerajinan tangan, bentuk hiasan dan gambar dari bahan kertas dengan memakai bantuan alat pemotong. Sumantri, (2015) mengemukakan bahwa menggunting adalah memotong berbagai aneka kertas atau bahan-bahan lain dengan mengikuti alur garis atau bentukbentuk tertentu, merupakan salah satu kegiatan yang mengembangakan motorik halus anak koordinasi mata dan tangan dapat berkembang melalui kegiatan menggunting. Saat menggunting jarijemari anak akan bergerak mengikuti pola bentuk yang digunting.

Suratno, (2005) menyatakan bahwa kegiatan menggunting membutuhkan ketrampilan menggerakkan otot-otot tangan dan jari-jari untuk berkoordinasi dalam menggunting sehingga bisa memotong kertas, kain atau yang lain sesuai yang diinginkan seperti menggunting yang berpola, menggunting dan melipat untuk membentuk gambar, membentuk pola ataupun yang lain.

\section{Media Kertas Origami}

PAUD merupakan salah satu bentuk pendidikan formil, adapaun yang menjadi tujuan program kegiatan belajar anak yaitu untuk membantu meletakan dasar kearah perkembangan sikap, pengetahuan, keterampilan, dan kegiatan media pembelajaran. Banyak sekali kegiatan media pembelajaran bermain anak, salah sataunya adalah media kertas origami yang dapat meningkatkan kreatifitas salah satunya adalah dapat mengasah 
kreatifitas dan imajinasi anak.

Selanjutnya Hamalik dalam Arsyad menyatakan bahwa pemakaian media pembelajaran dalam proses belajar mengajar dapat membangkitkan keinginan dan minat yang baru membangkitkan motivasi dan rangsangan kegiatan belajar, dan bahkan membawa pengaruh-pengaruh psikologi terhadap anak.

Secara umum kertas origami hampir sama dengan kertas biasa hanya saja kertas origami dari segi desain dan warnanya lebih beragam sehingga menjadi lebih menarik untuk digunakan sebagai media pembelajaran. Media pembelajaran adalah hal yang sangat penting dan diperlukan dalam proses pembelajaran untuk anak usia dini agar kegiatan pembelajaran dan tujuan pembelajaran bisa tercapai dengan baik dan berjalan dengan efektif serta efisien. Seperti yang telah dijelaskan Brigges dalam Sadiman bahwa, media adalah segala alat fisik yang dapat menyajikan pesan serta merangsang siswa untuk belajar

\section{METODELOGI PENELITIAN}

Menurut Sugiyono, (2013) metode penelitian diartikan sebagai cara ilmiah untuk mendapatkan data dengan tujuan dan kegunaan tertentu. Untuk memecahkan masalah harus menggunakan cara atau metode tertentu yang sesuai dengan pokok masalah yang akan dibahas. Metode tersebut dipilih agar penelitian dapat menghasilkan datadata akurat dan dipercaya kebenarannya.

Metode penelitian yang digunakan dalam penelitian ini adalah penelitian tindakan kelas. Menurut Syamsudin dan Damianti, (2011) metode penelitian tindakan kelas adalah penelitian tindakan menekankan kepada kegiatan tindakan dengan mengujicobakan suatu ide kedalam praktik atau situasi nyata dalam

(C) 2021, JoEE, Jurnal of Early Childhood. PGPAUD e-ISSN: 2775-7870 skala yang mikro, yang diharapkan kegiatan tersebut mampu memperbaiki dan meningkatkan kualitas pada situasi tertentu, misalnya pada proses belajar mengajar.

\section{Bagan Model Penelitian Tindakan Kelas Kemmis dan Mc. Taggart}

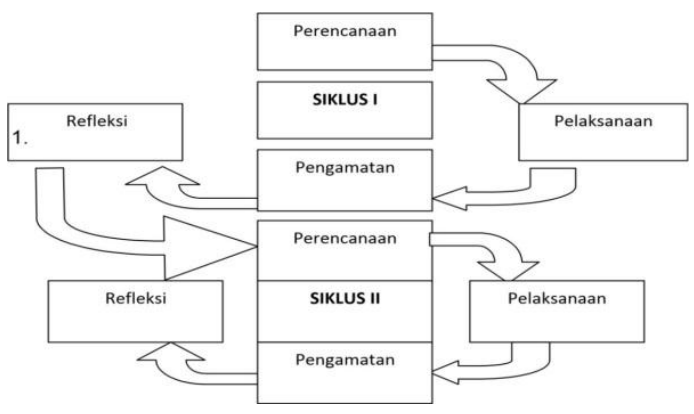

\section{HASIL DAN PEMBAHASAN Hasil}

Berdasarkan hasil pengamatan yang dilakukan peneliti, terkait dengan aspek perkembangan motorik halus selama observasi pembelajaran berlangsung anak mengalami kesulitan dan memerlukan bimbingan, seperti ketika anak menggunting pola, terlihat jelas anak masih memerlukan bantuan guru untuk mengajari cara menggunting mulai dari memegang gunting dan menggerakan tangan. Anak masih sangat memerlukan adanya bimbingan dan stimulus agar anak memeiliki keterampilan motrik halus yang berhubungan dengan keterampilan gerak kedua tangan, mampu menggerakan angota tubuh yang berhubungan dengan gerak jari jemari seperti kesiapan menulis, menggambar, mampu mengkoordinasikan antara mata dan jari, aktifitas tangan dapat dikembangkan melalui kegiatan menggunting berpola.

Berdasarkan hasil penelitian data yang terkumpul dari kelas berupa nilai anak dan catatan anekdot yaitu kejadian luar biasa yang terjadi selama penelitian adapun nilai anak yang diambil pada 
| Nia Kurniasih, Ahmad Yanuar Syauki dan Ana Lisnia. Penggunaan Kertas Origami Untuk Meningkatkan Keterampilan Motorik Halus Melalui Kegiatan Menggunting Berpola Kelompok B Tk El-Izdihar-Rajeg

penelitian ini ialah nilai pada pertemuan kedua siklus yaitu Siklus 1 dan nilai disetiap siklus lebih tinggi jika dibandingkan dengan pertemuan pertama pada setiap siklusnya.

\section{Pembahasan}

Berdasarkan hasil pengamatan yang dilakukan peneliti, terkait dengan aspek perkembangan motorik halus selama observasi pembelajaran berlangsung anak mengalami kesulitan dan memerlukan bimbingan, seperti ketika anak menggunting pola, terlihat jelas anak masih memerlukan bantuan guru untuk mengajari cara menggunting mulai dari memegang gunting dan menggerakkan tangan. Anak masih sangat memerlukan adanya bimbingan dan stimulus agar anak memiliki keterampilan motorik halus yang berhubungan dengan keterampilan gerak kedua tangan, mampu menggerakkan anggota tubuh yang berhubungan dengan gerak jari jemari seperti kesiapan menulis, menggambar, mampu mengkoordinasikan antar mata dan jari, aktivitas tangan dapat dikembangkan melalui kegiatan menggunting berpola.

Berdasarkan hasil penelitian data yang terkumpul dari kelas berupa nilai anak dan catatan anekdot yaitu kejadian luar biasa yang terjadi selama penelitian. Adapun nilai anak yang diambil pada penelitian ini ialah nilai pada pertemuan kedua siklus yaitu Siklus 1 dan nilai pertemuan di siklus 2. Hal ini dikarenakan nilai pada pertemuan kedua disetiap siklus lebih tinggi jika dibandingkan dengan pertemuan pertama pada setiap pertemuan di Siklus 2. Hali ini dikarenakan nilai pada pertemuan kedua siklusnya. Catatan yang diperoleh selama penelitian.

Berdasarkan hasil observasi dari sebelum tindakan ke siklus I dan II dapat dilihat perbandingan persentase hasil belajar. Dari data yang diperoleh dapat diketahui pencapaian hasil belajar anak dalam menggunting berpola dengan media kertas origami pada anak kelompok B TK El-Izdihar mengalami peningkatan. Keterangan tersebut menunjukan peningkatan yang sangat baik dalam keterampilan motorik halus anak dalam proses penelitian tindakan kelas yang dilaksanakan. Pada pertemuan kedua siklus II ini, dapat diketahui bahwa kemampuan rata-rata anak didominasi dengan keterampilan motorik halus anak menggerakkan jari jemari dalam memegang gunting serta dapat menggunting dengan luwes mengikuti pola gambar dengan tepat.

Hasil observasi sebelum tindakan dan observasi sesudah tindakan pada siklus I dapat dilihat perbandingan persentase hasil belajar, terlihat jelas bahwa keterampilan motorik halus anak sebelum tindakan siklus I mengalami peningkatan. Sebelum ada tindakan keterampilan motorik halus anak pada pra tindakan pada kriteria kurang baik dari segi ketepatan 40.0\%. Setelah adanya tindakan pada Siklus I dan Siklus II keterampilan motorik halus anak semakin meningkat. Pada siklus II pertemuan 2 terlihat segi ketepatan 90.0\%. 
Berdasarkan hasil pembelajaran yang dilaksanakan pada pertemuan ke 2 siklus II ini, disimpulkan bahwa keterampilan motorik halus anak sudah berkembang sangat baik. Nilai perkembangan keterampilan motorik halus anak yang diperoleh telah memenuhi target indikator keberhasilan yang sudah ditentukan sebelumnya.

Penelitian yang telah dilakukan merupakan penelitian tindakan kelas yang terdiri dari 2 siklus. Setiap siklus terdiri dari perencanaan, pelaksanaan, atau tindakan, observasi, dan refleksi. Hasil yang diperoleh pada siklus ini didapat dari data yang berupa lembar observasi. Dari data lembar observasi tersebut hasilnya digunakan untuk mengetahui peningkatan yang terjadi pada anak.

Analisis data dalam penelitian ini terjadi secara interaktif baik sebelum, saat dan sesudah penelitian. Sebelum penelitian dilakukan peneliti, telah melakukan analisis yaitu dalam menentukan rumus masalah yang muncul, kemudian analisis juga dilakukan pada saat pengambilan data kemampuan awal anak. Analisis sebelum penelitian ini bertujuan mengetahui sejauh mana permasalahan dan kemampuan anak sehingga dapat dilakukan tindakan penelitian yang tepat. Berdasarkan hasil observasi tentang pelaksanaan pembelajaran beserta dampak dari stimulasi yang telah diberikan kepada anak, menunjukan bahwa permasalahan yang paling mendominasi yaitu terkait kegiatan menggunting dengan media kertas origami yang dilakukan di TK El- dengan permasalahan keterampilan motorik halus anak.

Kegiatan menggunting dengan media kertas origami tersebut dilaksanakan mulai o5 Juli 2021 sampai dengan 09 Agustus 2021. Kegiatan penelitian ini dilaksanakan dalam 2 siklus. Siklus pertama dilakukan 2 kali pertemuan dan siklus kedua dilakukan 2 kali pertemuan. Sebagai awal dari kegiatan penelitian tindakan, telah dilaksanakan kegiatan pra tindakan sebagai gambaran awal dari pelaksanaan penelitian tindakan kelas di TK El-Izdihar Rajeg.

Keterampilan motorik halus (fine motor skill) merupakan keterampilan yang memerlukan kemampuan untuk mengontrol otot-otot kecil atau halus untuk mencapai pelaksanaan keterampilan yang berhasil. Menggunting merupakan salah satu kegiatan yang sesuai dengan karakteristik perkembangan motorik halus anak. Perkembangan motorik halus anak usia 45 tahun ditekankan pada koordinasi gerakan motorik halus yang berkaitan dengan kegiatan meletakkan atau memegang suatu objek dengan menggunakan jari tangan.

Keberhasilan penelitian yang terlihat dalam penelitian, telah menunjukan adanya kesesuaian antara teori dengan hasil penelitian. Hal ini dapat terlihat dalam proses pembelajaran anak dalam

Izdihar Rajeg. Teori tersebut terkait dengan tujuan dari kegiatan 
| Nia Kurniasih, Ahmad Yanuar Syauki dan Ana Lisnia. Penggunaan Kertas Origami Untuk Meningkatkan Keterampilan Motorik Halus Melalui Kegiatan Menggunting Berpola Kelompok B Tk El-Izdihar-Rajeg

menggunting dengan media kertas origami dimana kegiatan menggunting dengan media kertas origami ini dapat melatih keterampilan motorik halus anak, melatih kelenturan jari, meningkatkan koordinasi otot, mata dan tangan, melatih ketelitian, melatih kesabaran anak.

Keberhasilan tersebut membuktikan bahwa kegiatan menggunting efektif digunakan untuk meningkatkan keterampilan motorik halus anak di TK ElIzdihar Rajeg. Dengan demikian, penelitian tindakan kelas yang dilaksanakan melalui kegiatan menggunting dengan media kertas origami ini dapat dikatakan berhasil serta mampu meningkatkan keterampilan motorik halus anak kelompok B TK ElIzdihar Rajeg.

\section{PENUTUP}

\section{Simpulan}

Berdasarkan hasil penelitian yang telah dilakukan dapat disimpulkan bahwa keterampilan motorik halus anak pada kelompok B TK El-Izdihar Kecamatan Rajeg Kabupaten Tangerang dapat meningkat dalam kegiatan menggunting pola dengan media kertas origami. Proses pembelajaran kegiatan menggunting dilakukan secara bertahap sesuai langkahlangkah pembelajaran, sehingga kemampuan motorik halus anak dapat meningkat secara bertahap. Melalui perancangan kegiatan yang memungkinkan anak berubah kelompok dan bergantian teman dan pemberian kesempatan anak untuk menceritakan hasil karya anak di depan kelas dapat meningkatkan kemampuan motorik halus anak kelompok B TK El-lzdihar Rajeg. Peningkatan keterampilan motorik halus anak dapat terlihat dari ketepatan anak dalam menggunting pola dengan menggunakan media kertas origami.

Peningkatan keterampilan motorik halus anak pada kelompok B TK El-Izdihar Rajeg, dapat dilihat dari nilai persentase keterampilan motorik halus anak pada kondisi awal sebesar 40.0\%, meningkat pada siklus I menjadi 60.0\% dan pada siklus II mencapai 90.0\%. Berdasarkan penelitian penilaian dari siklus II sudah mencapai 90\%, maka tercapaian nilai KKM sebesar 75\% - 80\%. Maka siklus ini dihentikan.

\section{Saran}

Berdasarkan hasil pembahasan dan kesimpulan dapat dikemukakan saransaran sebagai berikut:

Bagi Pendidik PAUD pembelajaran khususnya untuk aspek keterampilan motorik halus. Penggunaan kertas origami dalam kegiatan menggunting sangat efektif untuk meningkatkan keterampilan motorik halus dalam proses pembelajaran yang menarik dan menambah minat anak untuk menggunakan media kertas origami dalam kegiatan menggunting. 


\section{DAFTAR PUSTAKA}

Alvan Hazhari, Tb. Rahman, Trio Carifatul, Caca Komalasari, 2018. Kemampuan Motorik Halus Anak TK Al Misbah. Tulip: Ciruas

Arsyad, Azhar. 2011 Media Pembelajaran. Jakarta: Rajawali Press

Asmawati, Luluk. 2011. Pengelolaan Kegiatan Pengembangan Anak Usia Dini. Jakarta: Universitas Terbuka

Danim, Sudarman, 2010 Perkembangan Peserta Didik Bandung: Alfabeta

Departemen Pendidikan Nasional. 2007. Pedoman Pembelajaran Bidang Perkembangan Fisik Motorik di Taman Kakan-Kanak. Jakarta

Depdiknas. 2009. Peraturan Menteri Pendidikan Nasional (PERMEN) No.58 Tahun 2009. Jakarta: Depdiknas

Desmita. 2010. Psikolog Perkembangan. Bandung: Remaja Rosdakarya

Desni, M.Psi. 2010. Metode Pengembangan Motorik Halus Anak Usia Dini. Pontianak: Fakultas Keguruan dan Ilmu Pendidikan Universitas Tanjungpura

Hasan, Alwi, dkk. 2002. Kamus Besar Bahasa Idonesia. Jakarta: Balai Pustaka

Hasil Observasi. 2018. Dikelompok A Taman Kanak-kanak Apik Darusalam Langkapura Bandar Lampung.

Hermawan, Didik. 2007. Saat Anak Tumbuh. Surakarta: Media Insani Press $\begin{array}{lll}\text { Penerapan } & \text { Kegiatan } & \text { Melipat Kertas } \\ \text { Origami } & \text { Untuk } & \text { Meningkatkan }\end{array}$

Hoben Garry, Nielsen, Wendy, Hyland, Christopher. Blended Media: Stunded-Generated Mash-Ups to Promote Engagement with Science Content, 2008, International Journal of Mobile and Blended Learning, Vol. 8, No. 3 .

Indriani, Puput. 2018. Wawancara dengan guru dikelompok A Taman Kanakkanak Apik Darusalam Langkapura Bandar Lampung.

Janice J. Beaty, 2008. Observasi Perkembangan Anak Usia Dini.Jakarta: Kencana

Kemenag. 2011. Pedoman Penyusunan Perangkat Pembelajaran RA/BA. Jawa Tengah: Mapenda Kanwil Kemenag Provinsi

Kemal, Tekin Ali. 2016. Autonomous Motivation of Omani Early Childhood Pre-Service Teachers for Teaching. Early Child Development and Care, Vol. 186. No.7.

Kirstine, Hansen. 2016. The Relationship Between Teacher Perceptions of Pupil Attractiveness andAcademic Ability.British Educational Research Journal, Vol. 42. No.3.

Krassadaki. 2014. Adopting a Strategy for Enhacing Generic Skills in Engineering Education Industry and Higher Educations, Vol. 28. No. 3.

Mursid. 2015 Belajar Dan Pembelajaran PAUD. Bandung: Remaja Rosdakarya. 
| Nia Kurniasih, Ahmad Yanuar Syauki dan Ana Lisnia. Penggunaan Kertas Origami Untuk Meningkatkan Keterampilan Motorik Halus Melalui Kegiatan Menggunting Berpola Kelompok B Tk El-Izdihar-Rajeg

Nana, Sudjana. 2014. Penilaian Hasil Proses Belajar Mengajar. Bandung: Remaja Rosdakarya

Pusat Kurikulum Balitbang. 2007. Standar Isi Pendidikan Anak Usia Dini. Jakarta: Depdiknas

Sugiono, Bambang, 2013. Metode Penelitian Pendekatan Kuantitatif, Kualitatif, dan R\&D. Bandung: Alfabeta

Sujiono, 2015. Metode Pengembangan Fisik, Tangerang Selatan: Universitas Terbuka

Sumantri, 2005. Model Pengembangan Keterampilan Motorik Anak Usia Dini. Jakarta: Mendiknas

Rudiyanto, d Ahmad, 2016 Perkembangan Motorik Kasar dan Motorik Halus Anak Usia Dini. Lampung: Darusalam Press

Sadiman, Arif S, dkk. 2011. Media Pendidikan. Jakarta: Rajawali Press.

Suratno. 2005. Pengembangan Kreatifitas Anak Usia Dini. Jakarta: Depdiknas

Susanto, Ahmad. 2011. Perkembangan Anak Usia Dini. Jakarta: Kencana

Wiyana, Navan Ardy. 2016. Psikologi Perkembangan Anak Usia Dini. Yogyakarta: Gava Media

Yudrik, Yahya. 2011. Psikologi Perkembangan. Jakarta: Kencana

Yusuf, LN, Syamsu. 2016. Psikologi Perkembangan Anak dan Remaja. Bandung: Remaja Rosdakarya 